\title{
Camphor Oil
}

National Cancer Institute

\section{Source}

National Cancer Institute. Camphor Oil. NCI Thesaurus. Code C72193.

The oil extracted from the wood of the Camphor tree Cinnamomum Camphora.

Camphor oil has anti-inflammatory and analgesic properties and is used for its aromatic properties, as an insect repellant, in embalming fluids, and in various topical skin preparations. 